\title{
PERAN SEL GASTRIN DALAM SALURAN PENCERNAAN
}

\author{
Lia Permatasari \\ Sunny Wangko \\ Sonny J.R. Kalangi
}

\author{
Bagian Anatomi-Histologi Fakultas Kedokteran Universitas Sam Ratulangi Manado \\ Email: ea1603@yahoo.com
}

\begin{abstract}
A gastrin cell is one of the enteroendocrine cells in piloric antrum that secretes gastrin. This gastrin is secreted when there are stimuli of food (protein, caffeine, red chili, and alcohol) and vagal nerves. Gastrin is released by exocytosis into the blood and then transported to parietal cells. Moreover, this gastrin interacts with CCK2 receptors in enterochromaffin-like cells, and then histamine is released that interacts with parietal cells to induce hydrochloric acid production. Besides that, gastrin stimulates the secretion of pancreatic enzymes, liver bile flow, and resting tonus of lower esophagal sphincter, but inhibits gastric emptying. Lack of gastrin can cause hypochlorhydria; on the other hand, Gasrin over-production can occur in inflammatory states such as gastritis and peptic ulcers, and pancreatic tumors (Zollinger-Ellison syndrome).
\end{abstract}

Keywords: gasrin, gastrin cell, hydrochloric acid, parietal cell

\begin{abstract}
Abstrak: Sel gastrin merupakan salah satu sel enteroendokrin yang terletak dalam antrum pilorus dan berfungsi menyekresi hormon gastrin. Gastrin disekresi saat terjadi rangsangan seperti makanan (protein, kafein, cabe merah dan alkohol) serta rangsangan vagus. Gastrin dilepaskan secara eksositosis ke dalam darah dan diangkut ke sel parietal. Gastrin berinteraksi dengan reseptor CCK2 (CCK2R) pada sel enterochromaffin-like (ECL), dan melepaskan histamin yang kemudian berinteraksi dengan sel parietal untuk menginduksi sekresi asam lambung. Selain itu gastrin merangsang sekresi enzim pankreas, aliran empedu hati, tonus istirahat sfingter esofagus bagian bawah, tetapi menghambat pengosongan lambung. Kekurangan gastrin dapat menyebabkan terjadinya hipoklorhidria. Kelebihan gastrin dapat terjadi beberapa keadaan inflamasi lambung seperti gastritis dan ulkus peptikum serta adanya tumor pankreas gastrinoma (sindrom Zollinger-Ellison).
\end{abstract}

Kata kunci: gastrin, sel gastrin, asam lambung, sel parietal

Makanan merupakan kebutuhan pokok manusia. Makanan yang dikonsumsi akan dicerna oleh alat-alat percernaan yang ada di dalam tubuh manusia. Makanan yang dimakan mempunyai cita rasa yang berbedabeda. Cita rasa pedas dan asam merupakan makanan yang banyak digemari masyarakat dewasa ini. Kebiasaan makan seperti ini seringkali mengakibatkan banyaknya keluhan penderita pada sistem pencernaan.

Penderita dengan keluhan nyeri pada lambung merupakan keluhan terbanyak, mulai dari yang akut sampai kronik, seperti gastritis akut dan ulkus peptik. Asam lambung dapat merusak dinding lambung itu sendiri, karena sifat asam yang korosif (mengikis). ${ }^{1,2}$

Peregangan serta adanya jenis makanan tertentu (antara lain protein) dalam lambung memicu dikeluarkannya hormon gastrin dari bagian mukosa antrum. Gastrin dibentuk oleh sel $\mathrm{G}$ di dinding lateral kelenjar pada bagian antrum pilorus mukosa lambung. Gastrin disekresikan oleh sel-sel dalam lambung dan merangsang produksi asam hidroklorat oleh sel parietal lambung 
dan meningkatkan pergerakan dari dinding lambung. ${ }^{3}$

\section{SEL GASTRIN}

Gastrin pertama kali dideteksi oleh ilmuwan Britania John Sydney Edkins (1905), dan nanti dapat diisolasi dari lambung babi oleh Gregory dan Tracy (1964) di Liverpool. Endinks berpendapat bahwa sekresi asam lambung mungkin diatur oleh mekanisme analog dengan kontrol sekresi pankreas oleh hormon sekretin usus yang telah ditemukan oleh Bayliss dan Starling tiga tahun sebelumnya. Endinks kemudian menunjukkan bahwa bila ekstrak bagian terendah lambung disuntikkan ke vena jugularis, dapat merangsang sekresi asam lambung; bahan ekstrak ini disebut faktor aktif gastrin. ${ }^{4}$

\section{Histologi sel gastrin}

Sel gastrin (sel G) paling banyak terdapat di antrum pilori dengan jumlah mencapai $5 \times 10^{5} / \mathrm{cm}^{2}$ mukosa. Sel ini berbentuk piramid dengan apeks menyempit, yang dilengkapi mikrovili panjang. Granul sekresi berdiameter 200-350 $\mathrm{nm}$ dan terkumpul di basis sel (Gambar 2). Sebagian granul mempunyai bagian tengah padat, sedangkan lainnya berupa vesikel yang sebagian besar tanpa isi. ${ }^{3}$

Sebagai respon terhadap rangsangan vagus atau mengembangnya lambung, maka sel-sel $G$ menghasilkan gastrin yaitu hormon peptida yang merangsang motilitas lambung dan merupakan stimulator kuat terhadap sel-sel oksintik (sel parietal) untuk menghasilkan asam. Sel G juga mempengaruhi sel induk dalam kelenjar korpus agar berproliferasi dan berdiferensiasi menjadi sel oksintik. ${ }^{2}$

\section{Faktor-faktor yang mempengaruhi kerja sel gastrin}

Sel-sel endokrin khusus, sel $\mathrm{G}$ yang terletak di daerah kelenjar pilorus lambung menyekresikan gastrin ke dalam darah apabila mendapat rangsangan yang sesuai. ${ }^{5}$ Aktivitas sekresi lambung sangat ditingkat- kan awal makanan saat kemo dan mekano reseptor dalam rongga mulut, dirangsang oleh pengunyahan dan pengecapan makanan. Impuls aferen dari reseptor ini menuju ke otak dan diteruskan ke serat saraf eferen dalam saraf vagus yang bekerja langsung pada sel-sel oksintik untuk meningkatkan sekresi asam. Bersamaan waktu dalam neuron pleksus saraf intrinsik terangsang oleh aferen vagus membangkitkan impuls yang menginduksi sel $\mathrm{G}$ melepaskan gastrin. ${ }^{1}$

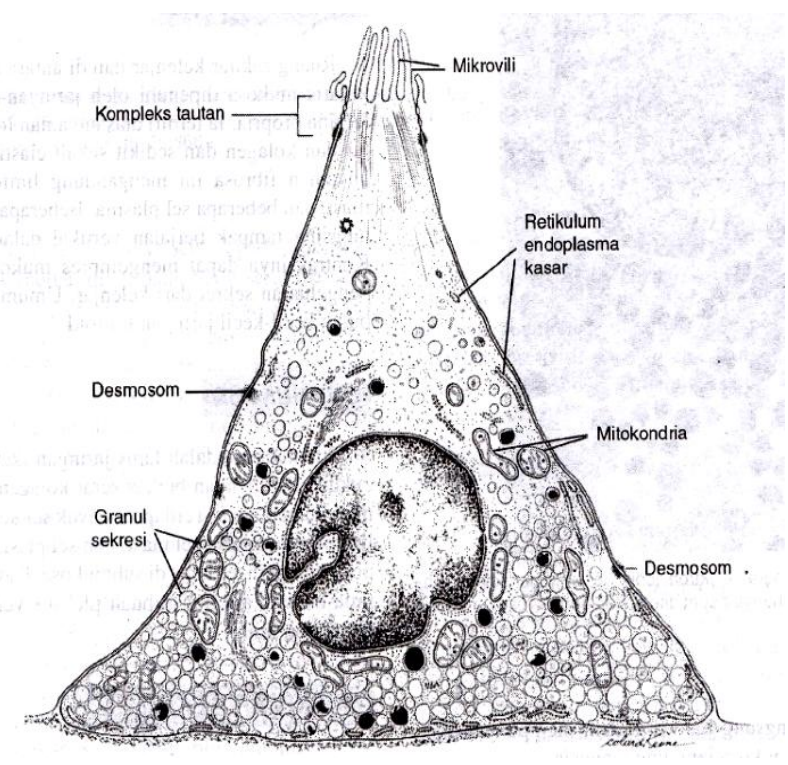

Gambar 2: Sebuah sel G. Sumber: Bloom, 2002. ${ }^{2}$

Adanya makanan dalam lambung merangsang sekresi asam dengan meningkatkan pelepasan gastrin, terutama protein dan produk hasil pencernaan protein yang terkandung dalam makanan. Glukosa oral dan lemak menyebabkan sedikit peningkatan gastrin serum tetapi tidak merangsang sekresi lambung. Kopi, baik yang mengandung kafein maupun yang bebas kafein, merangsang sekresi asam lambung dan kedua-duanya akan merangsang pelepasan gastrin. Minuman yang mengandung etanol merangsang sekresi asam lambung; dalam hal ini diduga adanya keterlibatan baik mekanisme lokal maupun sistemik. Kalsium intravena melibatkan rangsangan dalam sekresi asam lambung dan menghasilkan peningkatan minimal kadar gastrin 
serum. Pelepasan gastrin dihambat oleh somatostatin dan dirangsang oleh neuropeptida pelepas gastrin (gastrin releasing peptide, GRP). ${ }^{5-7}$

\section{Struktur kimia, penamaan dan tempat sekresi gastrin}

Gastrin merupakan hormon peptida besar yang disekresikan dalam beberapa bentuk di antrum pilori lambung. Pada saat terjadi rangsangan seperti makanan (protein), sel G menyekresi hormon gastrin dan dilepaskan secara eksositosis ke dalam darah dan diangkut ke sel parietal. Bentuk utama gastrin dalam mukosa antrum lambung ialah gastrin heptadekapeptida (G-17) yang mengandung 17 residu asam amino (dinamakan little gastrin) dengan daerah tempat aktifnya terminal karboksil amida tetrapeptida (Try-Met-Asp-Phe-NH2) (Gambar 3). Gastrin yang mengandung 14 asam amino dinamakan mini gastrin, sedangkan gastrin yang mengandung 34 asam amino big gastrin (G-34) ${ }^{5,8}$ Komposisi asam amino gastrin-17: Glu-Gli-Pro-Trp-Leu-GluGlu-Glu-Glu-Glu-Ala-Tir-Gli-Trp-Met-Asp$\mathrm{Fe}-\mathrm{NH}_{2}$.

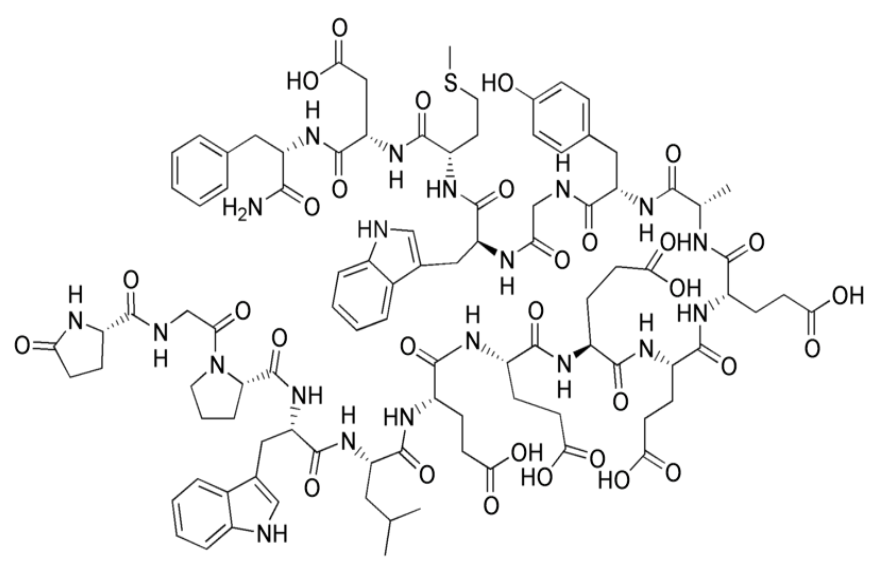

Gambar 3: Gastrin-17 asam amino (little gastrin). Sumber: Wikipedia, 2011. ${ }^{9}$

\section{Sekresi gastrin}

Walaupun umunya mekanisme dasar fungsi sel-sel kelenjar masih belum diketahui dengan pasti, terdapat bukti-bukti penelitian yang mengarah pada prinsipprinsip dasar sekresi oleh sel kelenjar, sebagai berikut: ${ }^{5}$

1. Zat nutrisi yang dibutuhkan untuk pembentukan sekresi harus berdifusi atau dipindahkan secara aktif dari kapiler ke dalam dasar sel kelenjar.

2. Banyak mitokondria yang terletak di dalam sel berdekatan dengan dasarnya menggunakan energi oksidasi untuk pembentukan adenosin trifosfat (ATP).

3. Energi dari ATP bersama-sama dengan zat-zat yang sesuai (disediakan oleh nutrien) kemudian digunakan untuk sintesis zat-zat organik. Umumnya sintesis ini terjadi dalam retikulum endoplasma dan kompleks Golgi. Ribosom yang melekat pada retikulum ini terutama berperan pada pembentukan protein yang akan disekresikan.

4. Bahan sekretorik dibawa melalui tubulus retikulum endoplasmik, melewati sepanjang vesikel kompleks Golgi yang terletak di dekat ujung sekretorik sel.

5. Dalam kompleks Golgi sekretorik zatzat tersebut kemudian dimodifikasi, ditambahkan, dipekatkan dan dikeluarkan ke dalam sitoplasma dalam bentuk vesikel sekretorik yang tersimpan pada ujung apikal sel-sel sekretorik.

6. Vesikel-vesikel ini tetap tersimpan sampai sinyal-sinyal pengontrol saraf atau sinyal hormonal memicu sel untuk mengeluarkan isi vesikel melalui eksostosis. Diduga sinyal kontrol awal meningkatkan permeabilitas membran sel terhadap ion kalsium sehingga ion tersebut masuk ke dalam sel. Ion kalsium kemudian memicu banyak vesikel untuk berfusi dengan membran sel dan kemudian membuka permukaan luarnya sehingga dapat mengeluarkan isinya ke luar sel (eksositosis).

Sel G merupakan tempat utama sintesis gastrin yang terletak di antrum pilori mukosa lambung, yang kemudian secara cepat dilepaskan ke dalam darah melalui eksositosis (Gambar 4a). Somatostatin yang 
disekresikan oleh sel D mengontrol sekresi gastrin oleh sel G melalui modifikasi transkripsi gen gastrin. Juga GRP yang berada dalam serabut saraf antrum mukosa lambung memfasilitasi sekresi gastrin melalui efek secretagogue. ${ }^{10}$ Setelah eksositosis dari sel $\mathrm{G}$, gastrin diangkut ke sel parietal (Gambar 4b). Gastrin berinteraksi dengan cholecystokinine receptor (CCK2R) pada sel enterochromaffin-like (ECL), melepaskan histamin yang kemudian berinteraksi dengan sel parietal untuk menginduksi sekresi asam lambung. Proses ini dimediasi oleh regulasi gastrin dan aktivitas histidin dekarboksilase yang meningkatkan produksi histamin. Sel D yang berada dalam mukosa oksintik dan pelepasan somatostatin menghambat sekresi asam lambung oleh difusi lokal dalam ruang intrasel atau lokal pada sirkulasi mukosa lambung. Somatostatin berkerja melalui dua cara yaitu dengan menghambat sekresi dan respon asam lambung untuk modulasi gastrin. GRP juga memiliki peran regulasi negatif dalam mukosa denga menangani pelepasan somatostatin oleh sel D. ${ }^{6,10}$

\section{Fungsi gastrin}

Peregangan lambung serta adanya jenis makanan tertentu dalam lambung memicu pengeluaran hormon gastrin dari bagian mukosa antrum. Hormon ini berefek memicu sekresi getah lambung yang sangat asam oleh bagian fundus lambung (Tabel 1). ${ }^{3}$ Gastrin juga mempunyai efek perangsangan kuat pada fungsi motorik lambung, yaitu meningkatkan aktivitas pompa pilorus sehingga berperan penting dalam mempermudah pengosongan lambung. Selain itu gastrin mempunyai efek konstriksi pada ujung bawah esofagus untuk mencegah terjadinya refluks isi lambung ke dalam esofagus selama peningkatan aktivitas lambung. ${ }^{8}$
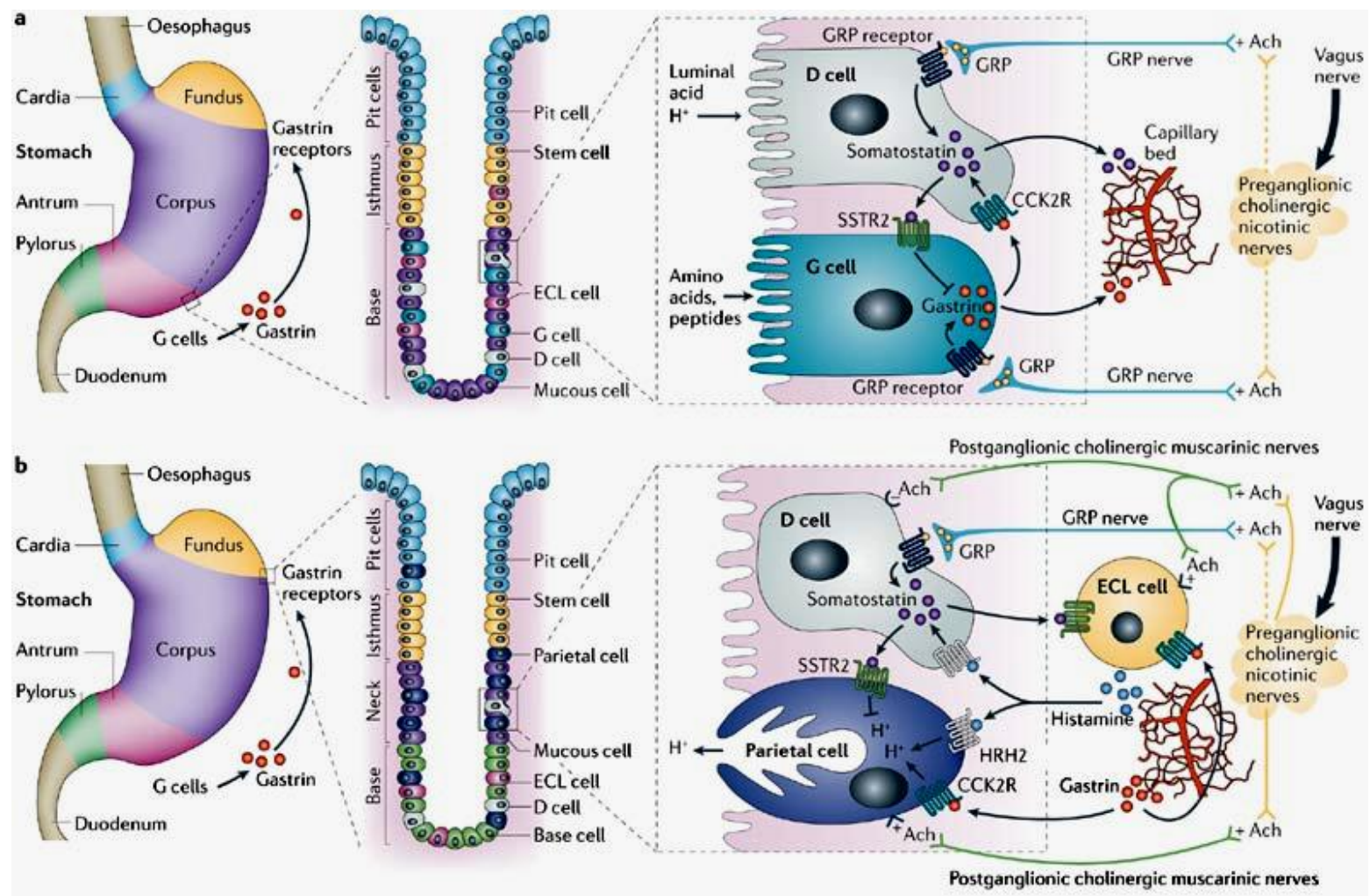
Copyright $\oplus 2006$ Nature Publishing Group
Nature Reviews | Cancer

Gambar 4. Sekresi gastrin a. Eksositosis gastrin. b. Interaksi gastrin dengan reseptornya pada sel ECL dan sel parietal. Sumber: Watson, 2006. ${ }^{10}$ 
Gastrin diabsorpsi ke dalam darah dan di kelenjar oksintik bagian bawah di dalam korpus lambung. Di sini gastrin merangsang sel-sel parietal secara kuat dan juga sel-sel peptik. Jadi, gastrin berperan penting dalam meningkatkan kecepatan sekresi asam hidroklorida oleh sel parietal. Kemudian asam hidroklorida memicu aktifitas refleks enterik yang tidak hanya meningkatkan sekresi asam hidroklorida lebih lanjut, tetapi juga secara sekunder merangsang sekresi enzim oleh sel-sel peptik hingga dua sampai empat kali lipat. ${ }^{9,11}$ Selain itu gastrin merangsang sekresi enzim pankreas dan aliran empedu hati, meningkatkan tonus istirahat sfingter esofagus bagian bawah, serta menghambat pengosongan lambung (Tabel 1). ${ }^{3}$

\section{BAHASAN}

Pada saat terjadi rangsangan oleh protein atau asam amino maka sel $G$ akan menyekresi gastrin. ${ }^{12,13}$ Gastrin dilepaskan dengan cepat secara eksositosis. Selain diangkut ke sel parietal, gastrin juga berinteraksi dengan reseptor CCK2 (CCK-2R) pada sel enterochromaffin-like (ECL), melepaskan histamin yang kemudian berinteraksi dengan sel parietal untuk menginduksi sekresi asam lambung. ${ }^{10}$ Gastrin juga telah terbukti memiliki beberapa fungsi tambah- an, diantaranya merangsang sekresi pepsin, faktor intrinsik, enzim pankreas dan pengeluaran insulin, meningkatkan tonus istirahat sfingter esofagus bagian bawah, serta menghambat pengosongan lambung. ${ }^{11}$

Gastrin mempengaruhi sel parietal untuk menyekresi asam lambung. Kekurangan gastrin dapat menyebabkan terjadinya hipoklorhidria. Dalam hal ini, makanan menjadi sulit atau lama dicerna dalam lambung sehingga pada saat masuk ke dalam duodenum belum lumat seutuhnya yang berakibat penyerapan makanan menjadi kurang maksimal. ${ }^{5}$

Kelebihan gastrin dapat terjadi pada beberapa keadaan inflamasi lambung seperti gastritis dan ulkus peptikum. ${ }^{14}$ Umumnya hal ini disebabkan oleh beberapa faktor, diantaranya terlalu banyak mengonsumsi makanan yang mengiritasi lambung seperti makanan pedas atau asam, kopi, minuman beralkohol, obat-obatan (aspirin), adanya asam lambung yang berlebihan, serta infeksi bakteri. $^{14}$

Ericson et al meneliti efek capsaicin terhadap sekresi gastrin pada antrum manusia, sebelum dan sesudah mengonsusmi cabe merah. Ternyata cabe merah merangsang sekresi gastrin dari kelenjar antrum manusia sedangkan diet rendah cabe menurunkan sekresi gastrin. Sebagai kesimpulan,

Tabel 1. Kerja gastrin dan makna fisiologiknya ${ }^{3}$

\begin{tabular}{lll}
\hline \multicolumn{1}{c}{ Kerja } & \multicolumn{1}{c}{ Makna fisiologik } \\
\hline $\begin{array}{l}\text { Merangsang sekresi asam dan pepsin } \\
\text { Merangsang sekresi faktor intrinsik }\end{array}$ & $\begin{array}{l}\text { Mempermudah pencernaan } \\
\text { Mempermudah absorpsi vitamin B } \mathrm{B}_{12} \text { dalam } \\
\text { usus halus }\end{array}$ \\
$\begin{array}{l}\text { Merangsang sekresi enzim pankreas } \\
\begin{array}{l}\text { Merangsang peningkatan aliran empedu } \\
\text { hati }\end{array}\end{array}$ & $\begin{array}{l}\text { Mempermudah pencernaan } \\
\text { Merangsang pengeluaran insulin } \\
\text { Merangsang motilitas lambung dan usus }\end{array}$ & $\begin{array}{l}\text { Mempermudah metabolisme glukosa } \\
\text { Mempermudah pencampuran dan pen- } \\
\text { dorongan makanan yang telah ditelan }\end{array}$ \\
Mempermudah relaksasi reseptif lambung & $\begin{array}{l}\text { Lambung dapat menambah volumenya tanpa } \\
\text { meningkatkan tekanan }\end{array}$ \\
$\begin{array}{l}\text { Meningkatkan tonus istirahat sfingter } \\
\text { esofagus bagian bawah }\end{array}$ & $\begin{array}{l}\text { Mencegah refluks lambung waktu pen- } \\
\text { campuran dan pengadukan } \\
\text { Menghambat pengosongan lambung }\end{array}$ & $\begin{array}{l}\text { Memungkinkan pencampuran seluruh isi } \\
\text { lambung sebelum di teruskan ke usus. }\end{array}$ \\
\hline
\end{tabular}


kandungan capsaicin pada cabe merah memiliki efek regulasi pada fungsi pencernaan terlebih pada sel-sel enteroendokrin. ${ }^{15}$

Raffeto et al membandingkan efek kopi tanpa kafein dan makanan yang tinggi protein dalam hal meningkatkan sekresi asam lambung. Hasil penelitian menunjukkan kopi tanpa kafein merupakan stimulan yang lebih kuat dibandingkan makanan tinggi protein untuk sekresi asam dan pelepasan gastrin. Asupan kafein juga dapat memudahkan helicobacter pilory berkembang biak dalam lambung. ${ }^{16}$

Inflamasi pada antrum akan menstimulasi sekresi gastrin yang selanjutnya akan merangsang sel parietal untuk meningkatkan sekresi asam lambung. Infeksi helicobacter pilory meningkatkan kadar gastrin terutama yang berasal dari mukosa antrum. Selain itu peningkatan sekresi gastrin juga terjadi akibat menurunnya kadar somatostatin dalam mukosa antrum yang berasal dari sel D. Dalam hal ini, secara fisiologis somatostatin atau sel D berfungsi sebagai acid brake, yang menekan fungsi sel $\mathrm{G}$ dan sekresi asam lambung oleh sel parietal. ${ }^{11,17}$

Peningkatan sekresi hormon gastrin juga dapat disebabkan oleh adanya tumor pankreas gastrinoma (sindrom ZollingerEllison) yang menghasilkan hormon gastrin dalam jumlah sangat besar. Peningkatan sekresi gastrin ini merangsang lambung untuk mengeluarkan asam sehingga memicu terjadinya ulkus peptikum. ${ }^{18}$ Gejala sindrom ini berupa nyeri perut ringan sampai berat akibat ulkus peptikum di lambung, duodenum dan tempat lainnya di usus, bisa sampai terjadi perforasi, perdarahan dan penyumbatan usus yang berakibat fatal. ${ }^{19}$

Beberapa jenis obat dapat menghambat sekresi asam lambung seperti proton pump inhibitor (PPI) dan $\mathrm{H}_{2}$ antagonist receptor. Dewasa ini telah dikenal lima macam PPI, yaitu pantoprazole, omeprazole, lanzoprazole, rabeprazole dan esomeprazole. ${ }^{18,20}$ PPI bekerja pada proses terakhir produksi asam lambung. Setelah diabsorbsi dan masuk ke sirkulasi sistemik, obat ini akan berdifusi ke sel parietal lambung, terkumpul di kanalikuli dan mengalami aktivasi menjadi bentuk sulfonamid tetra- siklik. Bentuk aktif ini berikatan dengan gugus sulfhidril enzim $\mathrm{H}^{+} \mathrm{K}^{+}$ATPase, sehingga terjadi penghambatan enzim tersebut. Penghambatan berlangsung antara 24-48 jam dan dapat menurunkan sekresi asam lambung baik yang basal maupun akibat stimulasi yang tidak bergantung dari perangsangan gastrin, histamin atau asetilkolin. $^{20}$

$\mathrm{H}_{2}$ receptor antagonist mengurangi sekresi asam lambung dengan cara menghambat reseptor histamin dalam sel-sel parietal lambung. H2 receptor antagonist terdapat dalam beberapa bentuk sediaan obat seperti simetidin, ranitidin dan famotidin. $^{20}$

Selain obat-obat yang dapat menghambat sekresi asam lambung, terdapat juga obat-obat yang dapat menetralkan asam lambung seperti golongan antasida. Antasida menetralkan kondisi lambung yang terlalu asam sehingga $\mathrm{pH}$ lambung meningkat yang berakibat mempengaruhi aktifitas enzim pepsin. Umumnya antasida merupakan basa lemah, dan terdiri dari zat aktif yang mengandung alumunium hidroksida, magnesium hidroksida, dan kalsium. ${ }^{20}$

Dalam menentukan pilihan obat untuk terapi farmakologis ulkus peptikum, perlu dilakukan secara rasional dengan mempertimbangkan sasaran terapi dan faktor-faktor penyebab. Untuk mengurangi sekresi asam lambung bisa digunakan PPI atau $\mathrm{H}_{2} \mathrm{re}$ ceptor antagonist, sedangkan untuk menetralkan asam lambung digunakan antasida. Jika penyebab disebabkan karena Helicobacter Pilory (HP) perlu diberikan antibiotik. Pada penderita dengan ZollingerEllison syndrome dapat diberikan PPI atau $\mathrm{H}_{2}$ receptor antagonist untuk menghambat sekresi asam. $^{21,22}$

\section{SIMPULAN}

Sel gastrin merupakan salah satu sel enteroendokrin yang terletak dalam antrum pilorus dan berfungsi menyekresi hormon gastrin. Sekresi gastrin dipengaruhi oleh beberapa faktor antara lain adanya makanan (protein) dalam lambung dan rangsangan vagus. Kelebihan gastrin dapat ter- 
jadi pada beberapa hal seperti gastritis, ulkus peptikum dan sindrom ZollingerEllison; pada keadaan ini dapat diberikan PPI atau $\mathrm{H}_{2}$ receptor antagonist untuk menghambat sekresi asam lambung yang berlebihan.

\section{DAFTAR PUSTAKA}

1. Junqueira CL. Carneiro J. Histologi Dasar Teks \& Atlas (Edisi ke-10). Jakarta: EGC, 2007.

2. Bloom W, Fawcett DW. Buku Ajar Histologi (Edisi ke-12). Jakarta: EGC, 2002.

3. Price SA, Wilson LM. Patofisiologi Konsep Klinis Proses-proses Penyakit Volume 1 (Edisi ke-6). Jakarta: EGC, 2006.

4. Blakemor C, Jennett S. Gastrin. The Oxford Companion to the Body [homepage on the internet] 2001. Nodate [cited 20115 Sep]. Available from: http://www.encyclopedia. com/topic/Gastrin.aspx.

5. Guyton A, Hall J. Buku Ajar Fisiologi Kedokteran. Jakarta: EGC, 2007.

6. Mishra P, Senthivinayagam S, Rangasamy V, Sondarva G, Rana B. Mixed lineage kinase-3/JNK1 axis promotes migration of human gastric cancer cells following gastrin stimulation. Mol Endocrinol. 2010; 24(3):598-607.

7. Lamont JT, Travis AC, Liddle RA. Synthesis, secretion, and regulation of gastrointestinal peptides [homepage on the internet]. Nodate [cited 2011 May] 2011. Availablefrom:http://www.uptodate.com/contents/synthesis-secretionand-regulation-of-gastrointestinal peptides? source $=$ see_link\#H5.

8. Sircar S. Gastrointestinal hormones. Principles of Medical Physiology [homepage on the internet]. Nodate [cited 2011 Aug 15]; p:456-7. Available from:http://books.google.co. $\mathrm{id} /$ books?id=zFl7y5xqHj4C\&pg=PA456 $\& d q=$ mechanism+by+gastrin+cell+in+ga strin+hormone+production \&hl=id\&ei=T cY6TsvdL43QrQeC0fUB\&sa=X\&oi=bo ok_result\&ct=result\&resum $=8 \&$ ved $=0 \mathrm{C}$ E0Q6AEwBw\# $\mathrm{v}=$ onepage $\& \mathrm{q} \& \mathrm{f}=$ false.

9. Gastrin [homepage on the internet] 2011. Nodate [cited 2011 Sep]. Available from: http://www.answers.com/topic/ gastrin\#ixzz 1UhYjh35W.

10. Watson SA, Grabowska AM, El-Zaatari M, Takhar A. The macroscopic and microscopic cellular interactions of the human gastric antro-pyloric and corpic/fundic mucosa. Nature Reviews Cancer 6. 2006; p:936-46 doi:10.1038/ nrc2014. [cited 2011 Aug 4]

11. Zubieta P. New Human Physiology. Gastrointestinal Function and Disorder (Edisi ke 2) [homepage on the internet] 2011. Nodate [cited 2011 Aug 5]. Available from: http: //ww.zuniv.net/ physiology/book/chapter22.html.

12. Liddle RA, Physiology of gastrin. Editor: Lamont JT [homepage on the internet]. 2011. c2011 [updated 2011 April 13; cited 2011 Aug 10]. Available from:http://www.up-todate.com/ contents/physiology-of-gastrin.

13. Dockray GJ. Gastrin. Best Practice \& Research Clinical Endocrinology \& Metabolism [serial online]. 2004 Dec [cited 2011 Aug 12];18(4):555-68. Available from:http://www.bprcem. com/article/ S1521-690X\%2804\%2900049$1 /$ abstract.

14. Munoz V, Varasa A, Tomaz, Pardo L, Rafael. Diagnostico Serologico de Gastritis Atrofica con una Combinacion de Pepsinogeno I y II, Gastrina-17 y Anticuerpos Anti-Helicobacter Pylori. Gastroenterol Hepatol. 2007;30 (10):567-71.

15. Ericson A, Mohammed NE, Petersson F, Kechagias S. The effect of capsaicin on gastrin secretion isolated human antrum glands: before and after ingestion of red chilli [homepage on the internet] 2009. Nodate [cited 2011 Aug 15]; p.491-98. Available from: http://www.ncbi.nlm. nih.gov/Pubmed/18668366.

16. Rafetto M, Grumet T, French G. Effects of caffeine and coffee on heartburn, acid reflux, ulcers and gerd [homepage on the internet]. 2004 [cited 2011 Aug 5]. Available from: http://teeccino. com/building_optimal_health/129/Caffe ine-\%26amp;WeightLoss.html.

17. Rani AA, Fauzi A. In: Sudoyo AW, Setiohadi B, Alwi I, Simadibrata MK, Setiati S, editors. Buku Ajar Ilmu Penyakit Dalam Jilid I (Edisi V). Jakarta: Internal Publishing, 2009; p. 501-12. 
18. Kenneth ELM, Derek G. Evidence that proton-pump inhibitor therapy induces the symptoms it is used to treat. Gastroenterology. 2009;137(1):80-87.

19. Rozengurt E, Walsh JH. Gastrin, CCK, Signaling and Cancer [homepage on the internet]. 2001 [cited 2011 Aug 2];63:49-76. Available from: Doi: 10.1146/annurev. Physiol 63.1.49. 2001.

20. Estuningtyas A, Arif A. Obat lokal. In: Gunawan SG, Setiabudy R, Nafrialdi, Elysabeth, editors. Farmakologi dan Terapi, Editor: Gunawan GS. Edisi:5. Jakarta: Gaya Baru. 2007. h.522-3

21. Sindrom Zollinger-Ellison [homepage on the internet]. c2011 (updated 2011 Sep
2; cited 2011 Sept 10). Available from: http://www.patient.co.uk/showdoc/4000 1304/

22. Sabiston DC. Gastrointestinal. Buku Ajar Bedah [homepage on the internet]. Nodate (cited 2011 Sept 5). Available from: http://books. google.co.id/books? id=9yqqTP6teIC\&pg=PA192\&lpg=PA1 $92 \& d q=$ histologi+selg\&source $=$ bl\&ots $=$ CGTOgvzoK $7 \&$ sig $=$ s1swn_34_oytJoKqGS2zZZ_1es\&hl=id \&ei=FMQCTru6H4bwrQfgwdTNCg\&s $\mathrm{a}=$ X\&oi=book_result\&ct=result\&resnu $\mathrm{m}=1 \& \mathrm{ved}=0$ CBUQ6AEwAA\# $\mathrm{v}=$ onepag $\mathrm{e} \& \mathrm{q}=$ histologi $\% 20$ sel $-\mathrm{g} \& \mathrm{f}=$ false 